\title{
Half-graben inversion tectonics revealed by gravity modeling in the Mikawa Bay Region, Central Japan
}

\author{
Ayumu Miyakawa* ${ }^{*}$, Tomoya Abe, Tatsuya Sumita and Makoto Otsubo
}

\begin{abstract}
The Mikawa Bay Region, central Japan, is characterized by many active faults recording Quaternary activities. It is, however, difficult to understand the overall tectonic character of the region due to a thick sedimentary cover. We report the first finding of Neogene basin inversion in southwest Japan by estimating the depth and structure of the basement surface in the Mikawa Bay Region by analyzing gravity data. Our gravity basement map and twodimensional density-structure model automatically determined using the genetic algorithm revealed a half-graben bounded on the south by the north-dipping Utsumi Fault. The motion of the Utsumi Fault, which inverted from normal faulting during the Miocene to recent reverse faulting, indicated the inversion of the half-graben. The timing of the inversion of the fault motion, i.e., the reverse faulting of the Miocene normal fault, can be compared with an episode of basin inversion observed at the eastern margin of the Japan Sea, northeastern Japan. The Takahama Fault in the southwestern part of the Nishi-Mikawa Plain is considered to have formed as a result of the backthrust of the Utsumi Fault under inversion tectonics. If the Takahama Fault is indeed the backthrust fault of the Utsumi Fault, the root of the Takahama Fault may be deep such that the Takahama Fault is seismogenic and linked to the 1945 Mikawa earthquake.
\end{abstract}

Keywords: Gravity survey, Inversion tectonics, Mikawa Bay Region, Nishi-Mikawa Plain, Chita Peninsula, Utsumi Fault, Takahama Fault, Basement structure, Half-graben, Central Japan, Genetic algorithm

\section{Introduction}

The Japan Arc is situated in a zone of plate convergence, where crustal activity such as earthquakes is common (Fig. 1a). Throughout the Japan Arc, there are many faults that are potentially active in the Quaternary. This article is the case in the Mikawa Bay Region, central Japan, close to the Nagoya area, one of Japan's largest urban areas. The evaluation of fault activity is an important issue in Japan; however, it is difficult to understand the overall tectonic characteristics of these active faults due to thick sediments and sea area in the Mikawa Bay Region. The Nishi-Mikawa Plain, also called the Okazaki Plain, a central part of the Mikawa Bay Region, is

\footnotetext{
* Correspondence: miyakawa-a@aist.go.jp

Geological Survey of Japan, AIST, AIST Tsukuba Central 7, 1-1-1 Higashi, Tsukuba, Ibaraki 305-8567, Japan
}

\section{Springer Open}

(c) The Author(s). 2020 Open Access This article is licensed under a Creative Commons Attribution 4.0 International License, which permits use, sharing, adaptation, distribution and reproduction in any medium or format, as long as you give appropriate credit to the original author(s) and the source, provide a link to the Creative Commons licence, and indicate if changes were made. The images or other third party material in this article are included in the article's Creative Commons licence, unless indicated otherwise in a credit line to the material. If material is not included in the article's Creative Commons licence and your intended use is not permitted by statutory regulation or exceeds the permitted use, you will need to obtain permission directly from the copyright holder. To view a copy of this licence, visit http://creativecommons.org/licenses/by/4.0/. $1000 \mathrm{~m}$ ) from the Miocene to Holocene. Quaternary crustal movements of Chita Peninsula, which is surrounded by the sea (i.e., Chita Bay, Mikawa Bay, and Ise Bay), have been well recorded as the elevation distribution of several marine terraces in the Pleistocene (e.g., Makinouchi 1979).

In this study, we focus on the geological structure of the Mikawa Bay Region in order to understand regional fault dynamics. Several geological and geophysical studies have been previously undertaken for disaster mitigation in this region. Research conducted by the local government has revealed the basement structure beneath the plain and peninsula (Aichi Prefecture 2002a, 2002b, 2004, 2005). The top of the basement deepens to the west, although basement rocks are exposed in the 


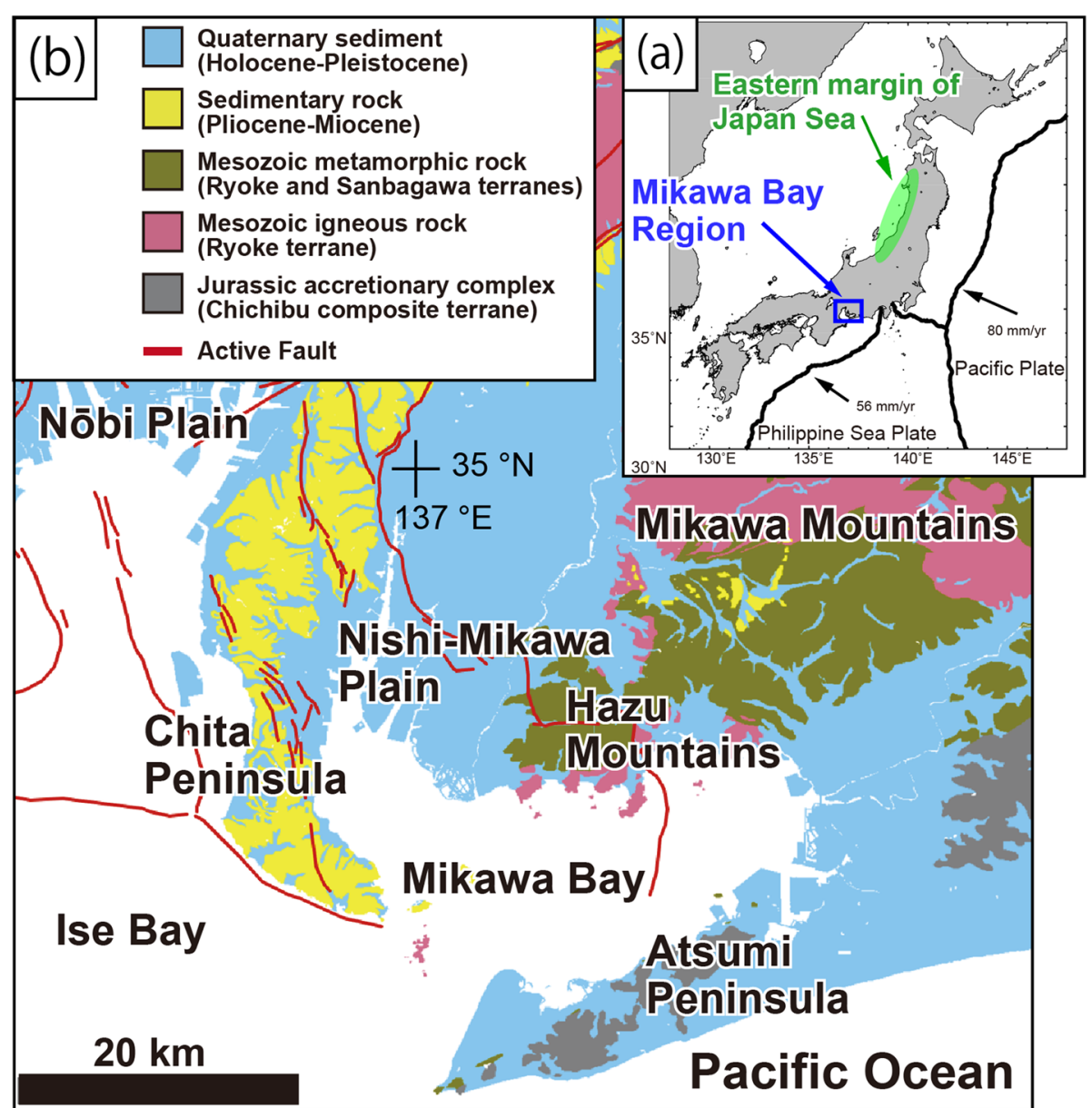

Fig. 1 Map showing the tectonic setting of the Japanese islands (a) and the geology of the study area (b) (National Institute of Advanced Industrial Science and Technology 2020b). a Thick black lines represent plate boundaries and black arrows represent relative plate motions (after Wei and Seno 1998). The blue rectangle represents the study area and the green shaded area is the eastern margin of the Japan Sea (see main text for discussion)

eastern area of the plain. The deepest part of the basement lies beneath the Chita Peninsula, where its depth is greater than $1500 \mathrm{~m}$ (Aichi Prefecture 2002a). Although active faults in the northwest part of the Nishi-Mikawa Plain and the northern part of the Chita Peninsula have been investigated using seismic reflection surveys to image their structures (Aichi Prefecture 1996), the active faults in the central part of the Nishi-Mikawa Plain and the south part of Chita Peninsula remain under discussion. One such active fault, the Utsumi Fault, runs along the southwestern coast of the Chita Peninsula. Although the Utsumi Fault is expected to play an important role in the formation of the Chita Peninsula, its subsurface structure is poorly known. Furthermore, a comprehensive understanding of the Takahama Fault, which distributes around a large urban area, has yet to be made clear.

In this study, we compiled existing gravity data together with our own gravity measurements in the northern part of the Mikawa Bay Region to image the structure of the basement beneath the Nishi-Mikawa Plain and Chita Peninsula. We revealed the detailed structure including the active faults' orientation using a genetic algorithm (GA) in the central part of the NishiMikawa Plain (i.e., the Takahama Fault) and along the southwestern edge of the Chita Peninsula (i.e., the Utsumi Fault). Then, we discussed the regional tectonics with a basin inversion and the conjugate relationship between the Utsumi and Takahama Faults.

\section{Study area}

The Mikawa Bay Region is located in the southern part of central Japan (Figs. 1 and 2). The Nishi-Mikawa Plain is in the northern Mikawa Bay Region, and the Chita Peninsula is at the west of the Nishi-Mikawa Plain, across Chita Bay. The Nishi-Mikawa Plain is mainly covered with the Pleistocene terraces and alluvial lowland, and its topography is relatively flat (Makimoto 


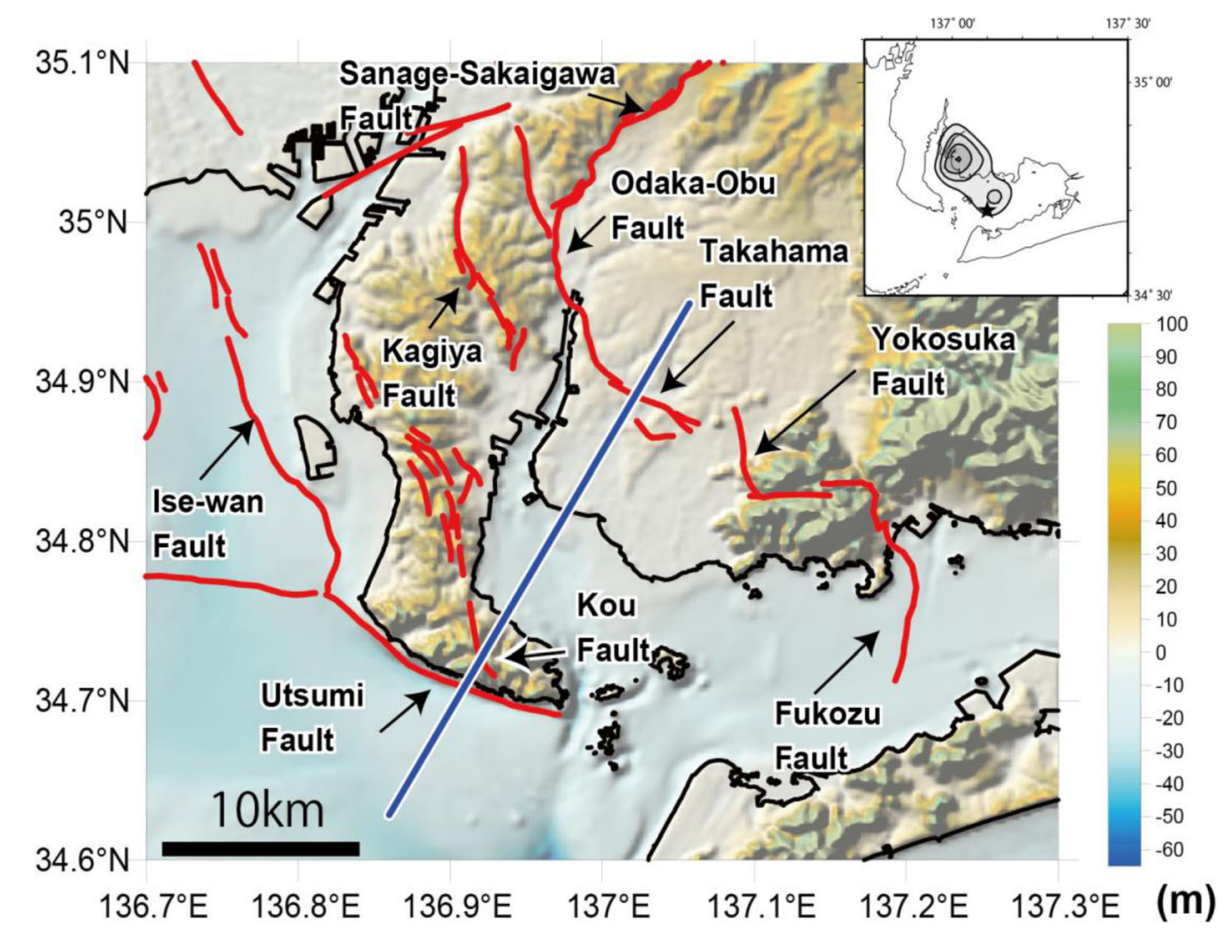

Fig. 2 Topography and active faults in the Mikawa Bay Region. Red lines represent the traces of active faults in Fig. $1 \mathrm{~b}$ (National Institute of Advanced Industrial Science and Technology, 2020a). The blue line indicates the profile line shown in Figs. 8, 9, and 10. The topography is illustrated using the $30 \mathrm{~m}$ gridded terrain data compiled by Murata et al. (2018). The top-right panel represents the slip distribution model of the 1945 Mikawa Earthquake (modified after Kikuchi et al. 2003). The increment of contour lines is $0.5 \mathrm{~m}$ and the star indicates the epicenter of the 1945 Mikawa Earthquake

et al. 2004). On the other hand, the Chita Peninsula has a relatively high topography. The hills of the Chita Peninsula approximately extend along the $\mathrm{N}-\mathrm{S}$ trend and primarily consist of the Middle Pleistocene terrace deposits (e.g., the Taketoyo and Noma formations) and Pliocene sedimentary rocks (the Tokai Group), whereas the Miocene sedimentary rocks (the Morozaki Group) are exposed in the southern part of the peninsula (Kondo and Kimura 1987). The Hazu Mountains and Mikawa Mountains, both of which consist of Mesozoic metamorphic rocks and granite, are located to the southeast and northeast of the Nishi-Mikawa Plain, respectively. The Atsumi Peninsula is elongated in an ENE-WSW direction south of the Nishi-Mikawa Plain across Mikawa Bay. Ise Bay lies at the west of the Chita Peninsula. The largest plain close to this region, the Nobi Plain, is situated to the northwest of the Chita Peninsula.

Active faults occur in and around the Nishi-Mikawa Plain and throughout the southern part of the Chita Peninsula (Fig. 2). Long-term evaluations along major active faults in Mikawa Bay Region are reported by the Headquarters for Earthquake Research Promotion (2002, 2004). The Sanage-Sakaigawa Fault is a NE-SW trending and the Odaka-Obu Fault is a NNW-SSE trending in the northern Nishi-Mikawa Plain. The Ise-wan Fault is along the northeastern edge of the Chita Peninsula. The Kagiya Fault is NNW-SSE trending in the northern the Chita Peninsula. The active faults in the northwest part of the Nishi-Mikawa Plain and the northern part of the Chita Peninsula such as the Ise-wan Fault (Okada et al. 2000) as well as the Odaka-Obu and Kagiya faults (Aichi Prefecture 1996) have been investigated using seismic reflection surveys to image their structures.

In this paper, we focused on the three major active faults in central-west part of Mikawa Bay Region whose structures remain under discussion: the Utsumi, Takahama, and Kou faults. The Utsumi Fault trends NWEW along the steep cliffs of the southern edge of the Chita Peninsula (Fig. 2). A closed depression suggesting a tectonic relief is recognized along the base of the steep cliffs in submarine topography (Goto 2013). Uplifting on the NE side of the Utsumi Fault is recorded in subsurface Quaternary sediments discovered via shallow seismic reflection surveys (Chujo and Suda 1971, 1972). This uplifting is believed to have formed the present topography of the southern Chita Peninsula. Gravity surveys around the southern part of the Chita Peninsula indicate a remarkably low Bouguer anomaly, suggesting thick sedimentary rocks and a deep basement surface 
(Chujo and Suda 1972). Deep seismic surveys able to image the shape of basement in this region have not yet been conducted. The Takahama Fault is a NW-SE trending active fault in the central Nishi-Mikawa Plain. Topographic features along the fault are, however, ambiguous in its southeastern part but clear in the northwestern part. The southwest-dipping reverse fault was discovered by seismic surveys conducted in the northwest (Aichi Prefecture 1996). Nonetheless, geophysical surveys, such as seismic surveys, have not yet been conducted in the southeastern part of the fault, with the exception of several boring surveys (e.g., Abe et al. 2019a, 2019b). The Kou Fault, another active one in the research area, is a N-S trending and east-dipping $\left(45^{\circ} \mathrm{E}\right)$ reverse fault (Kondo and Kimura 1987). Although the Kou Fault is thought to have been active at the southern end of the $\mathrm{N}-\mathrm{S}$ Kagiya fault zone traversing the Chita Peninsula, its slip rate is unknown (The Headquarters for Earthquake Research Promotion 2004). Some studies have classified the Kou Fault as estimated active fault which is not directly observed on the ground surface but is inferred from topography (Imaizumi et al. 2018).

The Mikawa earthquake ( $\mathrm{Mw}$ 6.6) occurred in the Mikawa Bay Region on January 13, 1945, causing more than 2300 causalities (Iida 1978). Kikuchi et al. (2003) analyzed seismograms of the Mikawa earthquake and revealed that its source was a NW-SE trending reverse fault with a slight left-slip component. The slip distribution mainly consisted of two asperities: one near the hypocenter and the other, with which the heavily damaged area is well correlated, $10-15 \mathrm{~km}$ to the northwest from the hypocenter (Kikuchi et al. 2003). Yamanaka (2004) reanalyzed the slip distribution in the 1945 earthquake using additional seismograms; this revised result also showed a large slip in the northwest part of the fault model. Several other studies concerning the Mikawa earthquake have noted the predominant role of N-S or E-W trending faults (i.e., the Yokosuka and Fukozu faults) in the southeast part of the Nishi-Mikawa Plain and the eastern part of the Mikawa Bay. Ando (1974) interpreted the ground movements as observed geodetically in terms of a N-S striking fault. Takano and Kimata (2009) reexamined the ground deformation caused by the earthquake through removing interseismic deformation and coseismic deformation resulting from the 1944 Tonankai earthquake ( $\mathrm{Mw}$ 7.9), which occurred $\sim 150$ km southwest off the Mikawa Bay Region. The estimated slips in the 1945 earthquake for the Yokosuka and Fukozu faults are $1.4 \mathrm{~m}$ and $2.5 \mathrm{~m}$, respectively. Sugito and Okada (2004) compiled geomorphic and geologic features of the surface rupture associated with the earthquake, and suggested that nearly pure thrust faulting along the southern $\mathrm{N}-\mathrm{S}$ trending section was the predominant mode of surface faulting during the earthquake. The two prevailing models (i.e., the NW-SE trending fault and the N-S trending fault) are not consistent, thus the structure of the source fault of the Mikawa earthquake is still under discussion.

\section{Datasets}

We used publicly available gravity datasets and an additional dataset that we observed across the southeast part of the Takahama fault in the central Nishi-Mikawa Plain. Most of the Mikawa Bay Region is covered by the publicly available datasets (Yamamoto et al. 2011; Geological Survey of Japan 2013; Gravity Research Group in Southwest Japan 2001) that we used for our analysis (Fig. 3a). Furthermore, in order to investigate the detailed structure of the southwest part of the Takahama fault, we conducted additional gravity surveys at 57 gravity stations (Supple. Table 1) using a Lacoste and Romberg gravimeter (G304). The network real-time kinematic techniques with the Virtual Reference Station method using Trimble R10 were applied to determine the location of the gravity stations. Bouguer anomalies were calculated with standard corrections (GSJ Gravity Survey Group 1989) for free-air, Bouguer, terrain and atmosphere, and normal gravity was removed in accordance with the Geodetic Reference System 1980 (GRS80). Terrain corrections were applied for a range of $60 \mathrm{~km}$ using the 30-m gridded terrain data compiled by Murata et al. (2018). This 30-m gridded terrain data in the study area mainly comprises 5 - and $10-\mathrm{m}$ gridded digital elevation map generated by the Geospatial Information Authority of Japan (GSI) and M7000 series digital bathymetry data provided by the Marine Information Research Center. The reduction density of $2.3 \mathrm{~g} / \mathrm{cm}^{3}$ was used to obtain the Bouguer anomaly. This reduction density was visually selected using the Nettleton method (Nettleton 1939) and allows the removal of topographic effects arising from sedimentary rocks exposed in the Chita Peninsula and Nishi-Mikawa Plain (Fig. 3b).

We used available elevation data of the basement surface to constrain the basement structure. We collected the elevation data from publicly available sources (Aichi Prefecture 2000, 2004; Kuwahara 1982; Ministry of Land, Infrastructure, Transport and Tourism 2008; National Research Institute for Earth Science and Disaster Resilience 2019; Yamada et al. 1984) and originally compiled in this study from boring data provide by Aichi Prefecture, Nishio City (Supple. Table 2). We also used geological maps to obtain some locations where the basement exposed to the ground surface (National Institute of Advanced Industrial Science and Technology, 2020b) (Supple. Table 2).

\section{Methods}

We estimated the structure of the basement surface (i.e., the thickness of the overlying sediments) in the Mikawa Bay Region by analyzing gravity anomaly data. 


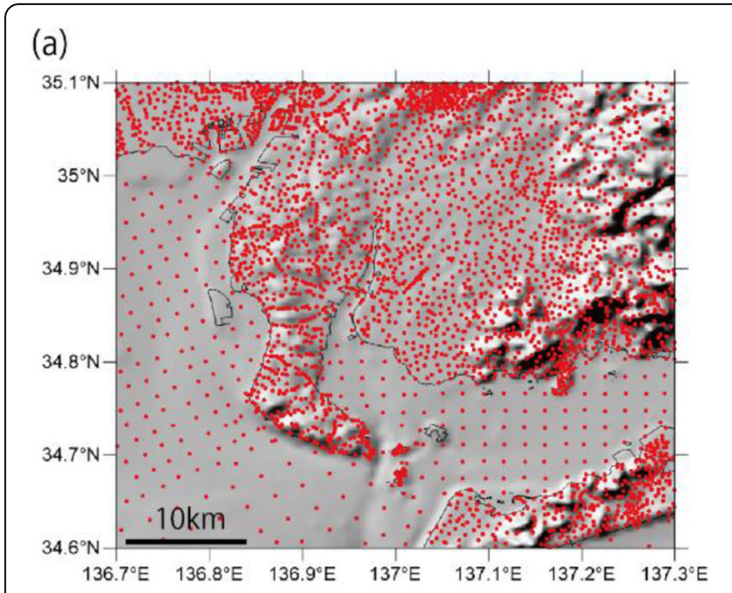

(c)

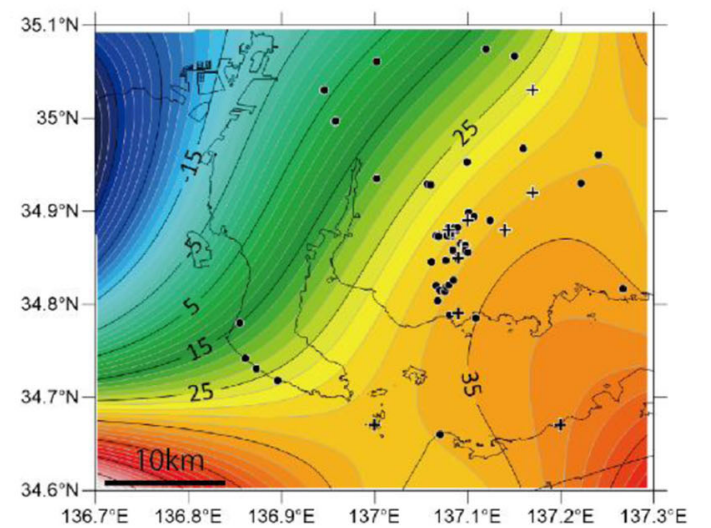

(b)

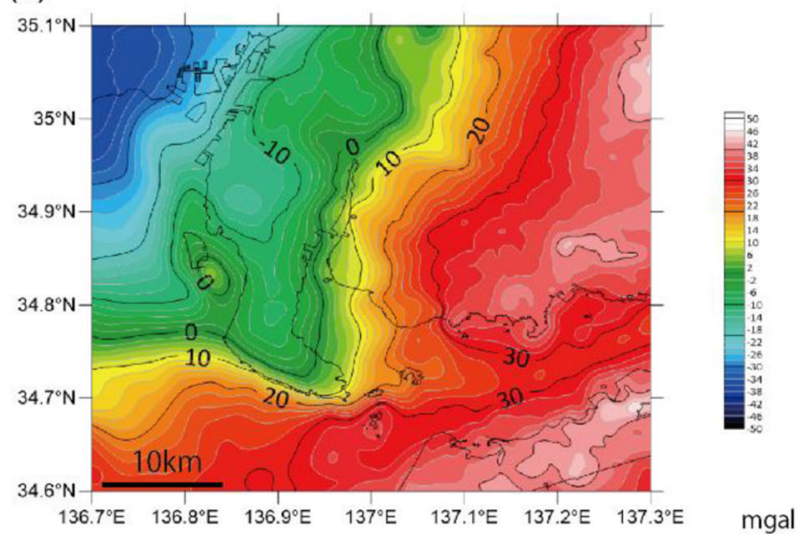

(d)

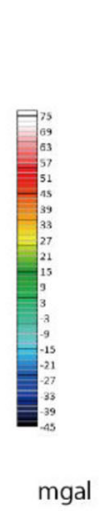

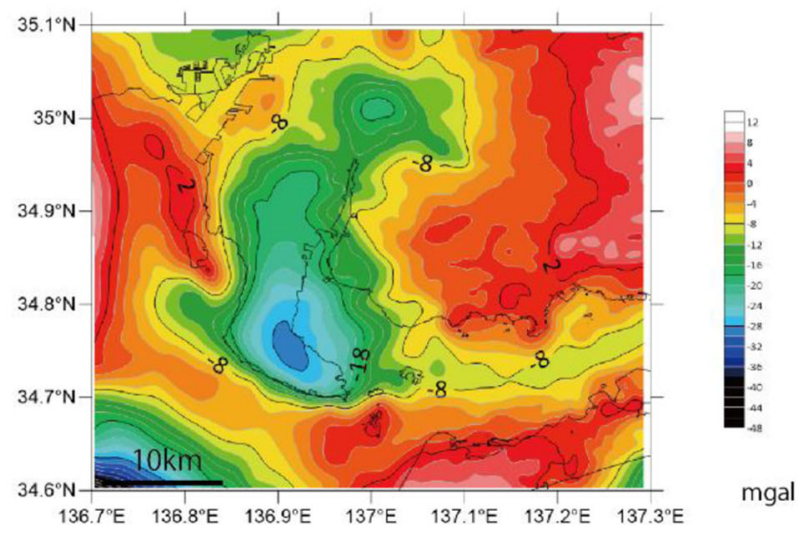

Fig. 3 Bouguer anomaly of the study area. a Red dots indicate the location of gravity stations used for this analysis. $\mathbf{b}$ Bouguer anomaly calculated with a reduction density of $2.3 \mathrm{~g} / \mathrm{cm}^{3}$. c Regional trend of the Bouguer anomaly. Black dots and crosses represent the boring locations and basement exposing locations, respectively. $\mathbf{d}$ Residual Bouguer anomaly obtained by deducting the regional trend (c) from the original Bouguer anomaly (b). The topography (a) is illustrated by using the $30 \mathrm{~m}$ gridded terrain data compiled by Murata et al. (2018)

\subsection{Gravity basement analysis}

To investigate the structure of the basement surface in the study area, we first estimated the regional trend of the Bouguer anomaly and obtained the optimal density contrast between the sediment/sedimentary rock and the basement rocks. Observed Bouguer anomaly contains mainly two components: regional trend originated by deep/large structure and local effects of the shallow geology. The regional trend of the Bouguer anomaly is caused by the deep/large structure such as subducting slab beneath Japan and/or the Moho structure of the region, and therefore the regional trend is usually observed as longwavelength components. On the other hand, shallow geological structure such as the distribution of different rock types or sediment thickness, which forms the focus of this study, produces short wavelength Bouguer anomalies. In the study region, rocks can be divided into two types based on density: lower-density sediments/sedimentary rocks, and higher-density basement rocks (i.e., granite and metamorphic rocks). The representative densities of these rock types exposed in this region are $\sim 1.4-2.3 \mathrm{~g} / \mathrm{cm}^{3}$ for sediments/sedimentary rocks and $\sim 2.5-2.9 \mathrm{~g} / \mathrm{cm}^{3}$ for granite and metamorphic rocks, respectively (Schön 2004). Knowing the density contrast between these two types of rocks allows us to estimate the thickness of the sediments/sedimentary rock covering the basement rocks from the residual Bouguer anomaly after the removal of the regional trend.

The regional trend of the Bouguer anomaly (long-wavelength components) and its optimal density contrasts are estimated based on the elevation of the basement observed in the borehole or outcrop. The observed Bouguer anomaly $\left(g_{B A}\right)$ with suitable terrain correction can be explained as the summation of the regional trend $\left(g_{\text {regional }}\right)$ and local effects (short-wavelength component) $\left(g_{\text {sediments }}\right)$.

$$
g_{\mathrm{BA}}=g_{\text {sediments }}+g_{\text {regional }}
$$

The regional trend is assumed to be expressed by the polynomial curved surface as follows: 


$$
g_{\text {regional }}=f(x, y \mid s),
$$

where $x$ and $y$ are coordinates in the rectangular coordinate system and $s$ is the coefficient of the polynomial curved surface $(f)$. The local effect is assumed to be derived from the density contrast between sediments/sedimentary rocks and basement rocks and the thickness of the sediments/sedimentary rocks. We modeled the effect of the sediments/sedimentary rock cover below sea level using an infinite horizontal plate:

$$
g_{\text {sediments }}=-2 \pi G \Delta \rho H,
$$

where $G$ is the gravitational constant $\left(6.674 \times 10^{-11}\right.$ $\left.\mathrm{m}^{3} / \mathrm{kg} \mathrm{s}^{2}\right), \Delta \rho$ is the density contrast between the sediments/sedimentary rocks and the basement rocks, and $H$ is the thickness of the sediments/sedimentary rocks below sea level (i.e., elevation of the basement surface). Here, the equation required to express the observed Bouguer anomaly can be written as follows:

$$
g_{B A}=-2 \pi G \Delta \rho H+f(x, y \mid s) .
$$

We obtained the regional component of the polynomial curved surface together with the optimal density contrast by solving the least squares problem for the basement surface elevation below sea level $\left(H_{i}\right)$ at the boring site $\left(x_{i}, y_{i}\right)$, and then the observed Bouguer anomaly at the site $\left(g_{B A i}\right)$ :

$$
\sum_{i=1}^{N}\left[g_{B A i}+2 \pi G \Delta \rho H_{i}-f\left(x_{i}, y_{i} \mid s\right)\right] \rightarrow \min ,
$$

where $N$ is the number of the sites at which the depth of the basement and the Bouguer anomaly is known. Minimizing the least square problem is achieved by finding the least square solution to the following simultaneous equations:

$$
\begin{aligned}
{\left[\begin{array}{c}
F_{1} \\
F_{2} \\
\vdots \\
F_{N}
\end{array}\right]=} & {\left[\begin{array}{ccccc}
A_{11} & A_{12} & \cdots & A_{1 M} & H_{1} \\
A_{12} & A_{22} & \cdots & A_{2 M} & H_{2} \\
\vdots & \vdots & \vdots & \vdots & \vdots \\
A_{N 1} & A_{N 2} & \cdots & A_{N M} & H_{N}
\end{array}\right] } \\
& \times\left[\begin{array}{c}
s_{1} \\
s_{2} \\
\vdots \\
s_{M} \\
2 \pi G \Delta \rho
\end{array}\right],
\end{aligned}
$$

where $\mathbf{A}$ is the function of the coordinate $(x, y)$. This formula can be written in $\mathbf{F}=\mathbf{A s}$. Then, the solution can be found by $\left(\mathrm{A}^{\mathrm{T}} \mathrm{A}\right) \mathrm{s}=\mathrm{A}^{\mathrm{T}} \mathrm{F}$.

We used 85 control points for the known elevation of the basement surface. The elevation of the basement at some control points is higher than sea level. For these points, the effect of basement topography above sea level on the Bouguer anomaly should be eliminated by applying appropriate corrections (free-air, Bouguer, and terrain) to the typical density of basement rock (Fig. 4). Hence, we calculated the gravitational corrections for each point at which the basement surface is above sea level, using a widely accepted reduction density of 2.67 $\mathrm{g} / \mathrm{cm}^{3}$ for granitic rocks. We calculated the corrections for the remainder of the points using a reduction density of $2.3 \mathrm{~g} / \mathrm{cm}^{3}$ according to the Nettleton method outlined above.

We solved the least square problem by using the 85 control points and setting a second-order polynomial curved function for the regional trend of the Bouguer anomaly. We employed the polynomial curved function for the regional trend following that of Makino and Endo (1999) (i.e., $f(x, y \mid s)=s_{1} x^{2} y^{2}+s_{2} x^{2} y+s_{3} x^{2}+s_{4} x y^{2}+$ $\left.s_{5} x y+s_{6} x+s_{7} y^{2}+s_{8} y+s_{9}\right)$, although it is different from the general second-order polynomial function. Thereafter, we obtained the optimal density contrast as $0.376 \mathrm{~g} / \mathrm{cm}^{3}$ (i.e., a sediment density of $2.294 \mathrm{~g} / \mathrm{cm}^{3}$ ) (Fig. 5) with the coefficients of the second-order polynomial curved function (Table 1). The obtained optimal density is almost the same as the value set for the sediments/sedimentary rock justified by using the Nettleton method $\left(2.3 \mathrm{~g} / \mathrm{cm}^{3}\right)$. The regional trend of the Bouguer anomaly along the second-order polynomial curved surface is highest in the southeast region and gradually decreases toward the northwest (Fig. 3c). This regional trend is consistent with results reported in the Aichi Prefecture (2002a). The estimation error at the control points is approximately $\pm 200 \mathrm{~m}$ according to the difference between the observed elevation and the calculated elevation of the basement surface (Fig. 6).

Finally, we obtained a map of the basement surface by extracting the regional trend from the observed Bouguer anomaly (Fig. 3d) and multiplying the constants of the infinite horizontal plate $(0.0158=-2 \pi G(-0.376) \mathrm{mgal} /$ m) (Fig. 7).

\subsection{Detailed modeling of the basement profile}

The estimation of the elevation of the basement surface assumes that the infinite horizontal plate is effective for determining the overall structure but unsuitable for the imaging non-flat structures (e.g., faults and slops). Hence, we conducted additional two-dimensional analysis to model the non-flat structures and to illuminate the detailed structure of the region, including the Utsumi and Takahama faults. We set a SW-NE trending survey line from the southwest of the Chita Peninsula to the central part of the Nishi-Mikawa Plain (Fig. 2b). The initial model was set as the profile of the gravity basement model estimated in the previous step. We then modified the initial model by adding the Utsumi and Takahama faults. Although we also attempted to model the Kou Fault crossing the survey line, we were unable 
(a) Definition of elevation and density

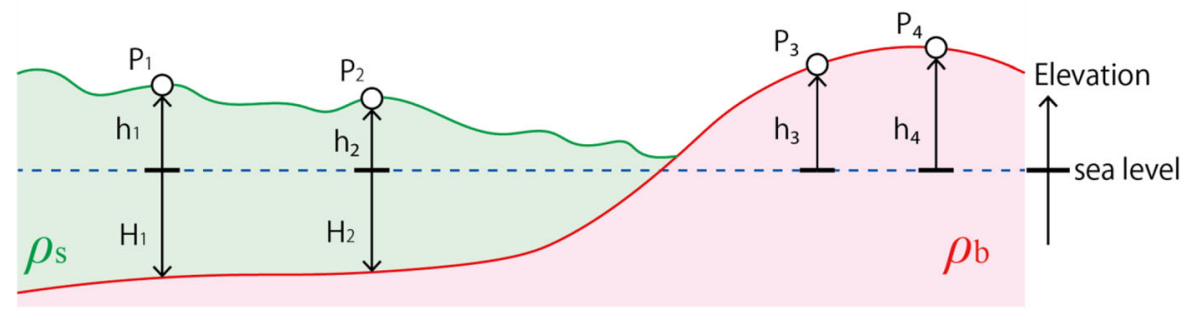

(b) Gravity correction ( $\mathrm{g}_{\mathrm{BA}}=\mathrm{g}_{\text {obs }}-\mathrm{g}_{\mathrm{n}}+\Delta \mathrm{g}(\rho) \fallingdotseq \mathrm{g}_{\text {regional }}+\mathrm{g}_{\text {sediments }}$ )

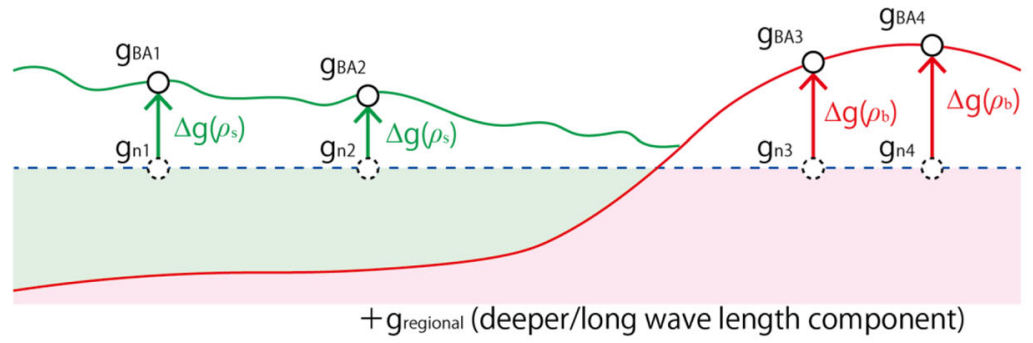

(c) Residual Bouguer anomaly ( $\mathrm{g}^{\prime}=\mathrm{g}_{\mathrm{BA}}-\mathrm{g}_{\text {regional }} \fallingdotseq \mathrm{g}_{\text {sediments }}$ )

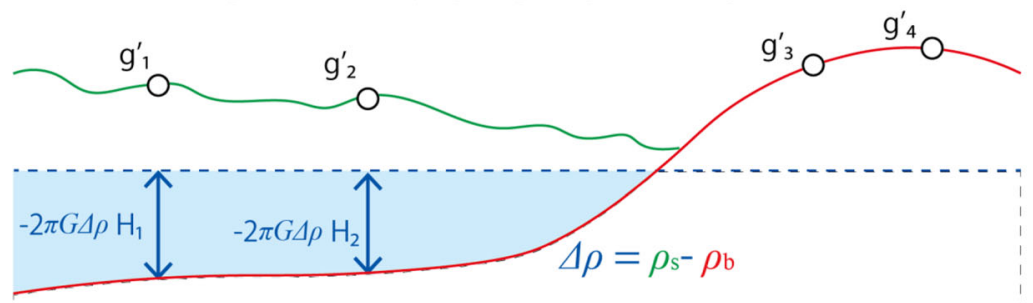

Fig. 4 Schematic diagrams showing the calculation of residual Bouguer anomalies at the boring sites and basement exposure points. a Definition of the elevation of points $(h)$ and the density of the basement $\left(\rho_{\mathrm{b}}\right)$ and one unit of sediments/sedimentary rocks $\left(\rho_{\mathrm{s}}\right)$. The elevation of the buried basement surface is represented by $H$. $\mathbf{b}$ Gravitational corrections $(\Delta g)$ (Bouguer, free-air and terrain correction) are calculated using the density of the rock exposed at the observation points. $g_{\mathrm{n}}$ is normal gravity in accordance with the Geodetic Reference System 1980 (GRS80). The corrected Bouguer anomaly $\left(g_{B A}\right)$ represents the Bouguer anomaly considered. c The residual Bouguer anomaly $\left(g^{\prime}\right)$ is obtained by removing the regional trend from the Bouguer anomaly $\left(g_{\mathrm{BA}}\right)$. The residual Bouguer anomaly must consist of the gravity anomaly from the thickness of the sediments/ sedimentary rocks (i.e., the elevation of the basement surface)

to constrain the optimal solution because the gravity data lacked sufficient sensitivity on deep and minor structures related to this fault (see details in the Results section). The validity of the model was evaluated by fitting the observed Bouguer anomaly, which is detrended from the regional trend. Gravity stations within $0.5 \mathrm{~km}$ onshore and $1.0 \mathrm{~km}$ offshore relative to the survey line were used. To select the best fit parameters, we employed the genetic algorithm (GA), a method for solving optimization problems based on a natural selection process that mimics biological evolution (e.g., Goldberg 1989). The method starts from an initial random population, comprising a number of individuals, which are vectors of model parameters, and iteratively improves the estimated solution. At each iteration, fitness to the objective solution is evaluated for each individual gives. The elites, which are fittest individuals, are selected for cross-over to produce offspring that replace the least fit individuals of the current iteration. A small percentage of this new population is arbitrarily mutated, depending on a given mutation rate, so different areas of the search space can be explored. This mutation helps avoid local minima in the optimization process. The new population is also evaluated, allowing only the fittest individuals to survive, and the process is repeated. Therefore, the GA which is able to solve nonlinear global optimization problems is suitable to find the best parameter set in our model.

We obtained the optimal basement model as follows. The synthetic Bouguer anomaly was calculated from the initial model with estimated density contrast $(-0.376 \mathrm{~g} /$ $\mathrm{cm}^{3}$ ) via the two-dimensional Talwani's method (Talwani 1973). Although the overall calculated Bouguer anomaly based on the initial model is consistent with the observed Bouguer anomaly, some discrepancy is 


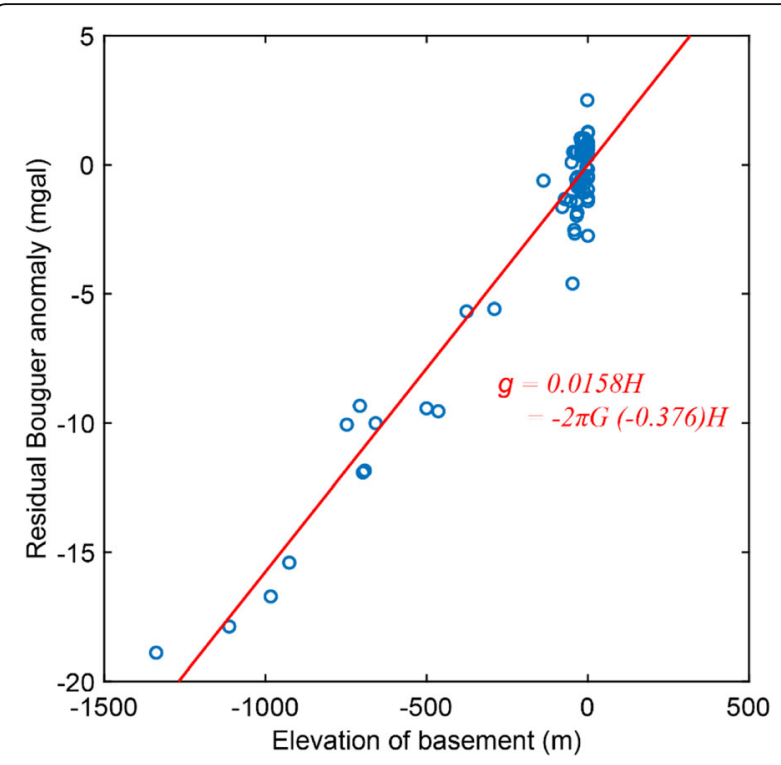

Fig. 5 Relationship between the elevation of the basement and the residual Bouguer anomaly at the boring site or basement exposure (Fig. 4). The red line represents the relationship between the elevation of the basement and the residual Bouguer anomaly by using the least square method

observed, especially around the faulted areas (green line in Fig. 8). To reduce these discrepancies, we set parameters to modify the basement structure: the dip of the Utsumi Fault, the dip of the Takahama Fault, the depth shift in the southwest part of the region, the depth shift in the northeast part of the region, the tilt correction of the basement between the Chita Peninsula and Nishi-Mikawa Plain, and the position of the center of tilt correction (see Supple. Figure 1). The dip of the Utsumi Fault in the deep basement is unknown because the depth of the seismic image across the Utsumi Fault is too shallow $(\sim 100 \mathrm{~m}$ in depth) to capture the shape of the basement (Chujo and Suda 1971, 1972). Hence, we set the dip of the Utsumi Fault to range from $30^{\circ} \mathrm{E}$ to $30^{\circ} \mathrm{W}$ (i.e., $30^{\circ}$ to $150^{\circ}$ from the east). The dip of the southeast part of the Takahama Fault, through which the survey line passes, is also unknown, although the dip of the northwest part of the fault was estimated to be $70^{\circ}$ to $80^{\circ} \mathrm{W}$ by seismic surveys (Aichi Prefecture 1996). Hence, we set the dip of the Takahama Fault to range from $30^{\circ} \mathrm{E}$ to $30^{\circ} \mathrm{W}$ (i.e., $30^{\circ}$ to $150^{\circ}$ from the east). The tip (surface position) of the Utsumi and
Takahama faults were fixed according to previous studies (Imaizumi et al. 2018; Abe et al. 2019a, 2019b); the tip of the Utsumi Fault was set at $0 \mathrm{~km}$ (i.e., with its origin in the horizontal direction), while the tip of the Takahama Fault was set at $22.98 \mathrm{~km}$. Even in the flat basement, the synthetic Bouguer anomaly calculated from the initial model is systematically lower than the observed Bouguer anomaly. Therefore, we set the depth shift in the southwest part $(-10-0 \mathrm{~km}$ in the horizontal direction) and the northeast part $(22.98-30 \mathrm{~km}$ in the horizontal direction) to range from -0.2 to $0.2 \mathrm{~km}$ and -0.1 to 0.1 $\mathrm{km}$ in the vertical direction, respectively. A tilt correction for the basement between the Chita Peninsula and the Nishi-Mikawa Plain ranges from $-2^{\circ}$ to $2^{\circ}$. The center of the tilt correction ranging from 15 to $18 \mathrm{~km}$ was also set to provide parameters that fit the lowest Bouguer anomaly observed in the Chita Peninsula.

The synthetic Bouguer anomaly at each observation point was calculated by the two-dimensional Talwani's method using a density-structure model with the parameters outlined above. The parameter set which produces the best fit model was searched using the GA (Table 2; Figs. 8 and 9). We set that the elite count and the crossover fraction were set to $5 \%$ of the population size and 0.8 , respectively. The optimization was terminated when the average change in the fitness value is small enough $\left(1.0 \mathrm{e}^{-6}\right)$. To validate the robustness of the GA analysis, we ran the GA 10 times and obtained almost the same results every time, within the range of a few degrees or meters, which is considered sufficient accuracy for the following discussion (Suppl. Table 3 and Suppl. Fig. 2). We selected the parameter set showing the lowest error from the 10 sets as the optimal parameter set (Table 2).

\section{Results}

\subsection{Basement surface structure around the Nishi-Mikawa}

\section{Plain}

The structure of the basement surface around Mikawa Bay Region is depicted from the Bouguer anomaly (Fig. 7). The basement surface is shallow at the east side of the Nishi-Mikawa Plain, consistent with the exposure of basement rocks in the Mikawa Mountains and Hazu Mountains east of the Nishi-Mikawa Plain. The basement surface deepens from the Nishi-Mikawa Plain to the Chita Peninsula, where its depth is greater than 1500

Table 1 Coefficient of the polynomial function representing the regional trend of the Bouguer anomaly

\begin{tabular}{|c|c|c|c|c|c|c|c|c|}
\hline$s_{1}$ & $s_{2}$ & $s_{3}$ & $s_{4}$ & $s_{5}$ & $s_{6}$ & $s_{7}$ & $s_{8}$ & $s_{9}$ \\
\hline 0.00007 & 0.00149 & -0.02301 & -0.00089 & 0.00083 & 1.34760 & -0.01037 & -0.88458 & 13.61115 \\
\hline
\end{tabular}

The $s_{i}$ is the coefficient of the following function.

$f(x, y \mid s)=s_{1} x^{2} y^{2}+s_{2} x^{2} y+s_{3} x^{2}+s_{4} x y^{2}+s_{5} x y+s_{6} x+s_{7} y^{2}+s_{8} y+s_{9}$, where $x$ and $y$ is local cartesian coordinates (km) from coorindates of an origin $137^{\circ} \mathrm{E}, 35^{\circ} \mathrm{N}$ 


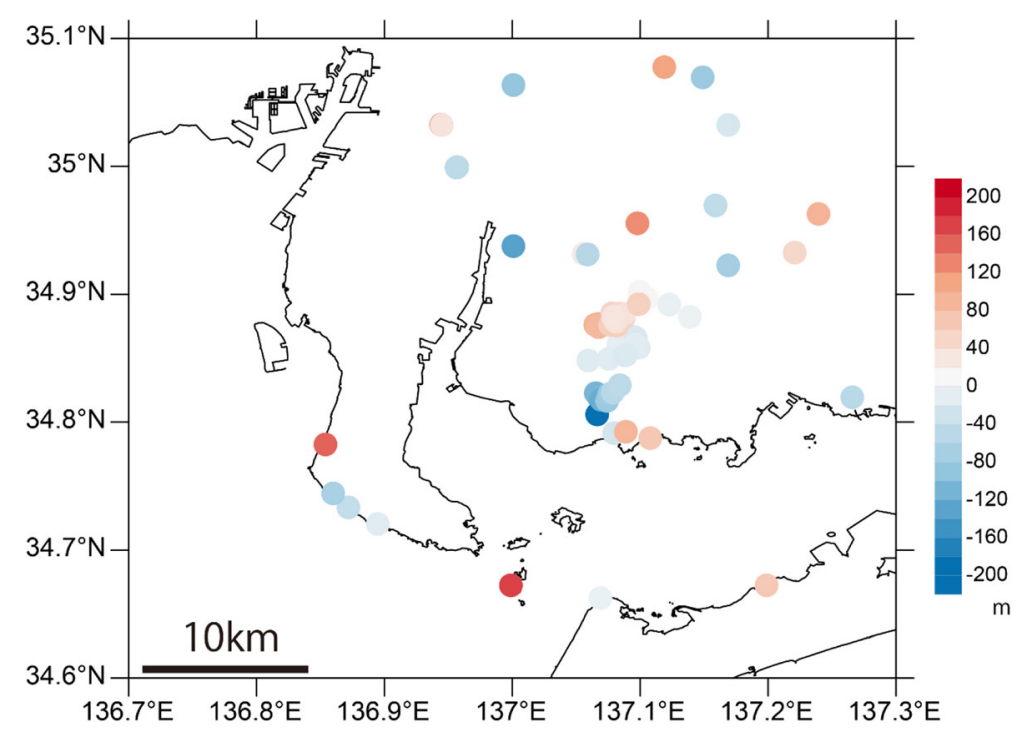

Fig. 6 Difference between the observed elevation of the basement surface and the calculated elevation of the basement surface (see Fig. 5)

$\mathrm{m}$. This trend is consistent with the results of the seismic survey conducted by Aichi Prefecture (2004). The depression of the basement beneath the Chita Peninsula continues to the north of the Nishi-Mikawa Plain.

A NNW-SSE elongated basement high exists in Ise Bay to the west of the northern Chita Peninsula (Fig. 7); we interpret it to be caused by reverse faulting on the Ise-wan Fault that was mapped by Okada et al. (2000). The basement surface becomes considerably shallow toward the west across the Utsumi Fault. Its depth in Ise Bay, far west of Chita Peninsula is, however, inconsistent with results obtained by the seismic reflection survey (Iwabuchi et al. 2000). This area, the Ise Bay far west of Chita Peninsula, is the west edge of our study field, where no boring sites were obtained to control basement surface, thus the regional trend of the estimated Bouguer anomaly might be inappropriate in this region.

\subsection{Fault-related basement surface structure in the Mikawa Bay Region}

The depth of the basement surface drastically changes across the Utsumi Fault (Fig. 8). The orientation of the Utsumi Fault indicates a structure like a normal fault that is high dip angle $\left(\sim 70^{\circ} \mathrm{E}\right)$ and that the vertical offset of the top-basement horizon is $\sim 2000 \mathrm{~m}$ (Fig. 8). The Takahama Fault is a reverse fault with a dip angle

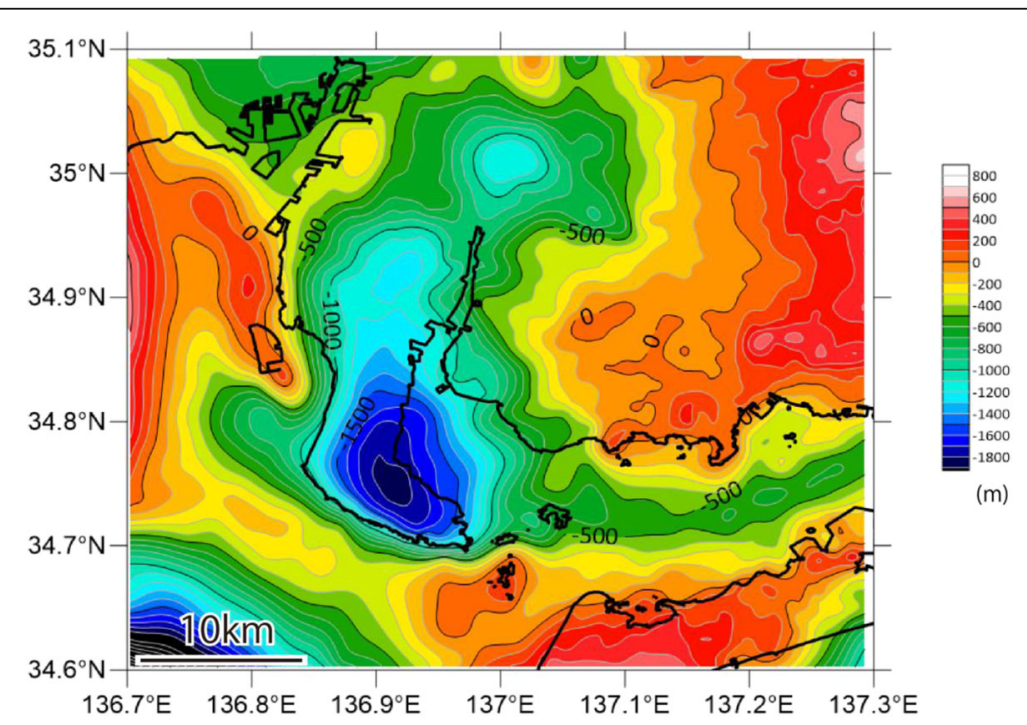

Fig. 7 Gravity basement map obtained using the relationship between the depth of the basement and the residual Bouguer anomaly (Fig. 5) based on the residual Bouguer anomaly map (Fig. 3d) 


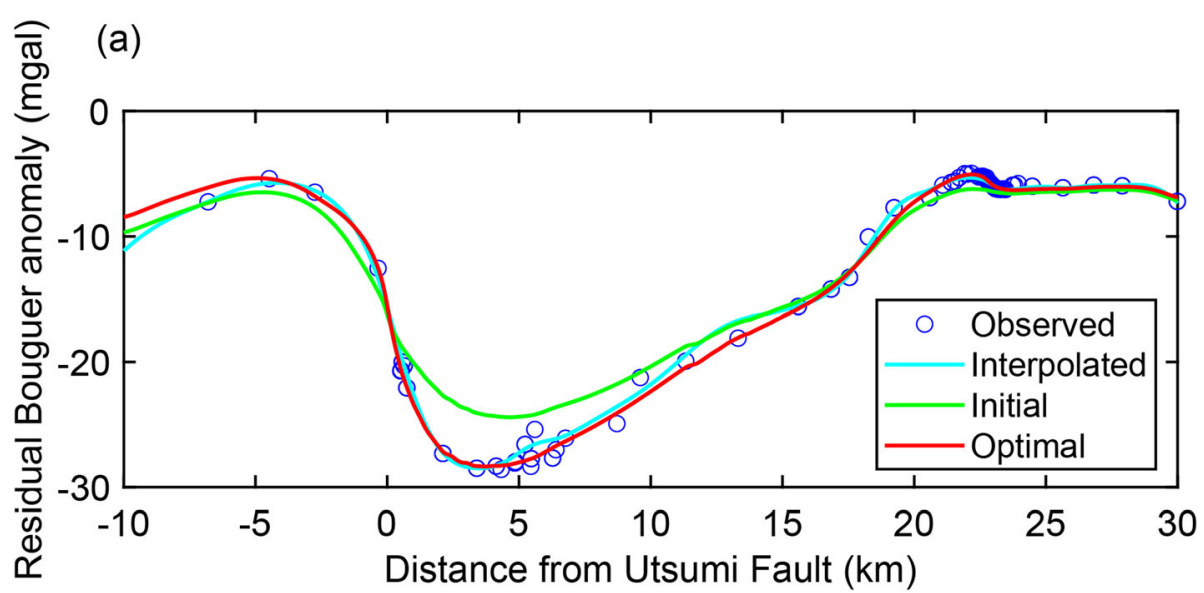

(b)

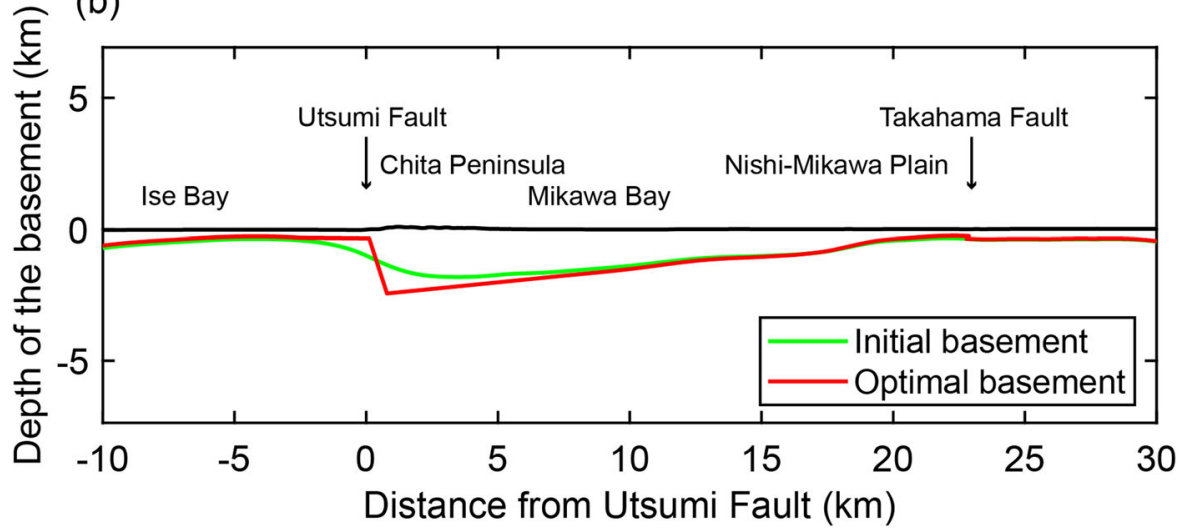

Fig. 8 Profiles of the Bouguer anomaly (a) and the topography of the basement surface (b). a The observed and interpolated residual Bouguer anomalies are represented by the open circles and cyan line, respectively. The interpolated residual Bouguer anomalies come from that of the Fig. 3d. The green line and red line represent the calculated Bouguer anomaly from the initial model (green in $\mathbf{b}$ ) and the optimum model (red in b) using the 2D Talwani's method. $\mathbf{b}$ The green line represents the initial model extracted from the gravity basement model (Fig. 7) along the survey line. The red line represents the optimum basement model obtained by selecting the best parameters (see Table 2). The black line represents the elevation of the ground surface. The origin of the $x$-axis is set as the tip of the Utsumi Fault in both $\mathbf{a}$ and $\mathbf{b}$

of $\sim 60^{\circ} \mathrm{E}$ (Fig. 8). This dip is consistent with the fault dip observed by seismic-reflection profiling across the northwestern part of the Takahama Fault (Aichi Prefecture 1996). The vertical offset is $\sim 200 \mathrm{~m}$, which is relatively smaller than that of the Utsumi Fault. The basement surface tilts and deepens from the Takahama Fault to the Utsumi Fault.

We attempted to incorporate the basement surface structure of the Kou Fault by including the Kou Fault with a $45^{\circ} \mathrm{E}$ dip. It is, however, difficult to constrain the structure arising from the Kou Fault. Even when setting the opposite geometry to that of the basement (i.e., reverse fault and normal fault), both synthetic Bouguer anomalies calculated from the conflicting models are within the range of the observed Bouguer anomaly (Fig. 10). The gravitational signal from the resulting small, deep structure is dull, such that the signal of the basement surface topography related to the Kou Fault cannot be constrained in our analysis.

Table 2 Optimum parameters for the 2D basement model

\begin{tabular}{lllllll}
\hline $\begin{array}{l}\text { Dip of } \\
\text { Utsumi }\end{array}$ & $\begin{array}{l}\text { Dip of } \\
\text { Takahama } \\
\begin{array}{l}\text { Fault } \\
\left({ }^{\circ} \mathrm{E}\right)\end{array}\end{array}$ & $\begin{array}{l}\text { Fault }\left({ }^{\circ} \mathbf{W}\right) \\
\text { basement Southwest }\end{array}$ & $\begin{array}{l}\text { Depth Shift of the } \\
\text { from the Utsumi Fault } \\
(\mathbf{k m})\end{array}$ & $\begin{array}{l}\text { Rotation of the basement } \\
\text { basement northeast } \\
\text { from the Takahama } \\
\text { Fault }(\mathbf{k m})\end{array}$ & $\begin{array}{l}\text { Rotation center of } \\
\text { between the Utsumi and } \\
\text { Takahama faults(deg to } \\
\text { anticlock wise) }\end{array}$ & $\begin{array}{l}\text { Mean } \\
\text { between the Utsumi } \\
\text { and Takahama faults } \\
(\mathbf{k m})\end{array}$ \\
\hline 72.1 & 61.5 & 0.095 & 0.019 & 1.0 & $\begin{array}{l}\text { absolute } \\
\text { error } \\
(\mathbf{m g a l})\end{array}$ \\
\hline
\end{tabular}



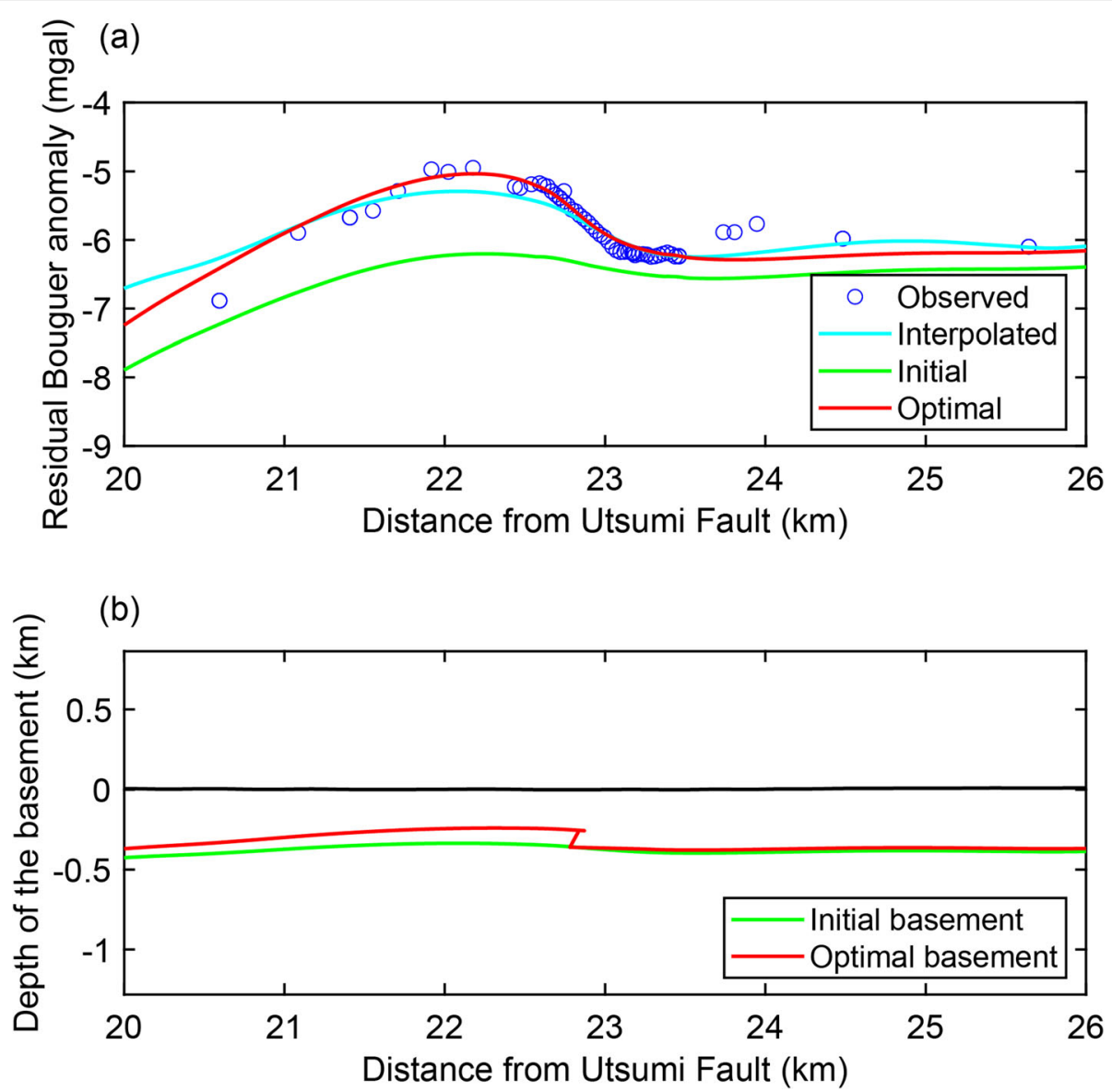

Fig. 9 Close-up views of the profiles of the Bouguer anomaly (a) and the topography of the basement surface (b) around the Takahama Fault. The tip of the Takahama Fault is located at $22.98 \mathrm{~km}$. a The observed and interpolated residual Bouguer anomalies are represented by open circles and the cyan line, respectively. The interpolated residual Bouguer anomalies come from that of the Fig. 3d. The green line and red line represent the calculated Bouguer anomaly from the initial model (green in b) and the optimum model (red in b) using the 2D Talwani's method. b The green line represents the initial model extracted from the gravity basement model (Fig. 7) along the survey line. The red line represents the optimum basement model obtained by selecting the best parameters (Table 2). The black line represents the elevation of the ground surface. The origin of the $\mathrm{x}$-axis is set at the tip of the Utsumi Fault in both $\mathbf{a}$ and $\mathbf{b}$

\section{Discussion}

\subsection{Inversion tectonics in the Mikawa Bay Region}

The topographic features of the basement surface depict a half-graben structure beneath the Chita Peninsula. Depression of the basement surface beneath the Chita Peninsula has been noted in previous studies (Aichi Prefecture 2002a, 2004; Chujo and Suda 1972). We found that the Utsumi Fault indicates a normal fault structure with a large gap, and the tilted basement surface forms the hanging wall of the Utsumi Fault (Fig. 8). These structural features correspond to a large halfgraben structure in the Mikawa Bay Region, where the Utsumi Fault is the edge fault of the half-graben.

The geometry of the basement surface and uplift forming the Chita Peninsula suggest the inversion tectonics of the half-graben in the Mikawa Bay Region. A discrepancy between the recent reverse faulting and the depressed basement beneath the Chita Peninsula was identified in a previous study (Chujo and Suda 1972). The recent NE side up reverse faulting (i.e., uplift of the Chita Peninsula side) is recorded in the Quaternary sediments. On the other hand, Miocene normal faulting of the Utsumi Fault is suggested from the thick Miocene sediments on the hanging wall (Aichi Prefecture 2005). Therefore, the motion of the Utsumi Fault is shown to have changed from normal faulting in the Miocene to recent reverse faulting (Aichi Prefecture 2005). This change of motion is interpreted as inversion tectonics related to the half-graben structure discovered herein (Fig. 11).

The lack of knowledge of the geometry of the basement surface by Kou Fault makes it difficult to clarify the role of Kou Fault in the inversion. As shown above, the gravity anomaly could not constrain the structure arising from the Kou Fault. This fact suggests that a displacement of the Kou Fault is less than that of the 

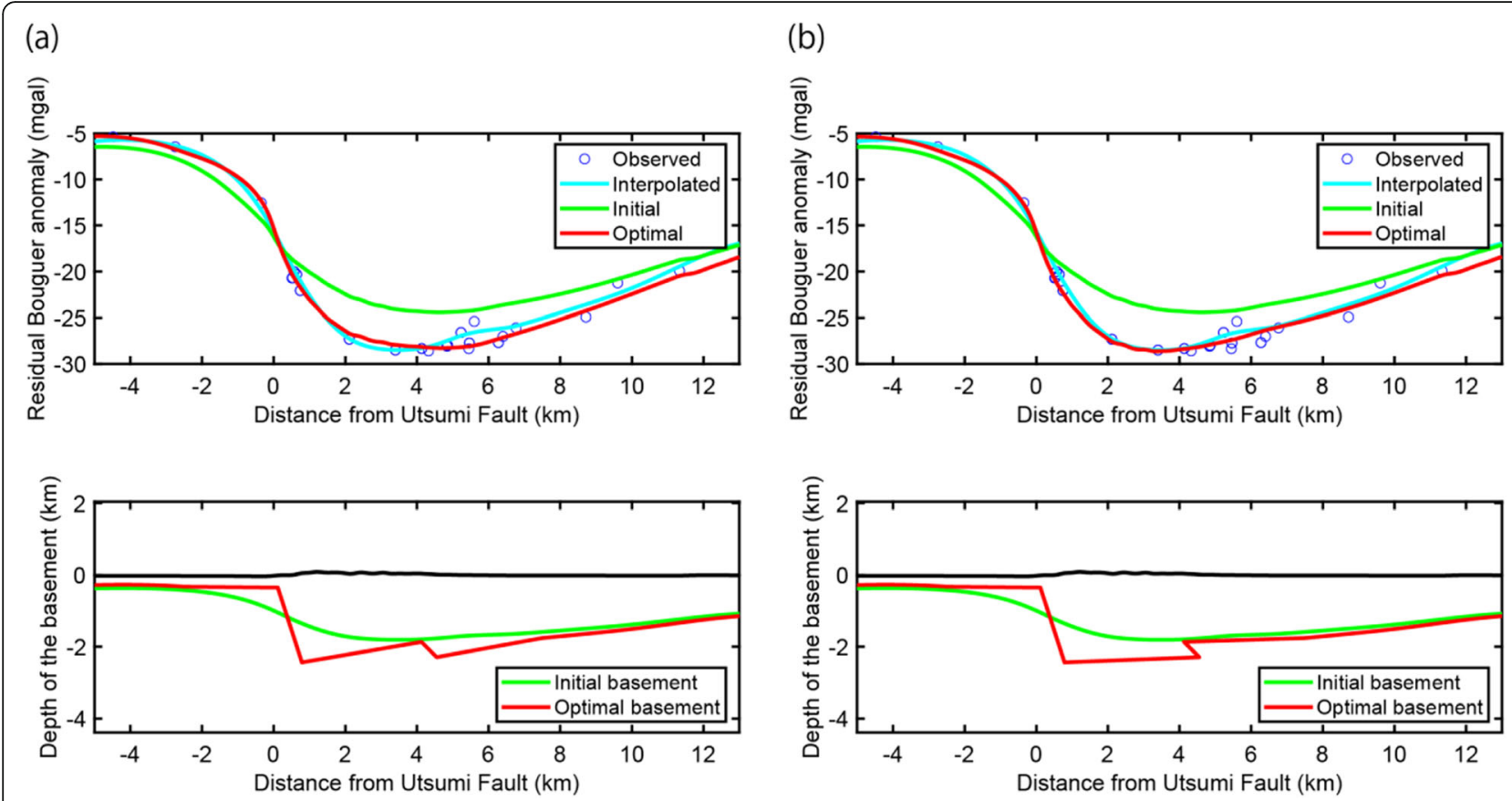

Fig. 10 Profiles of the Bouguer anomaly and the topography of the basement surface with $600 \mathrm{~m}$ of displacement along the Kou Fault at 2.26 $\mathrm{km}$ with a dip of $45^{\circ} \mathrm{E}$. a Reverse fault structure of the Kou Fault using the optimal basement model. $\mathbf{b}$ Normal fault structure of the Kou Fault using the optimal basement model. Lines and circles are same as shown in Fig. 8. The origin of the $x$-axis is set at the tip of the Utsumi Fault in both $\mathbf{a}$ and $\mathbf{b}$

Utsumi Fault during the inversion process. Therefore, the Kou Fault may be a minor branch fault of the Utsumi Fault, which is the master fault of the inversion. In contrast, the $\mathrm{N}-\mathrm{S}$ trending Kou Fault is oblique to the NW-SE trending Utsumi Fault. This geometrical discrepancy suggests an irrelevance between the Kou Fault and the Utsumi Fault, and the Kou Fault may have different history to the Utsumi Fault. To conclude the abovementioned issues, more detailed structural exploration is required.

(a)

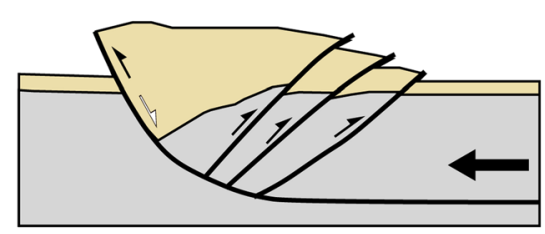

(b)

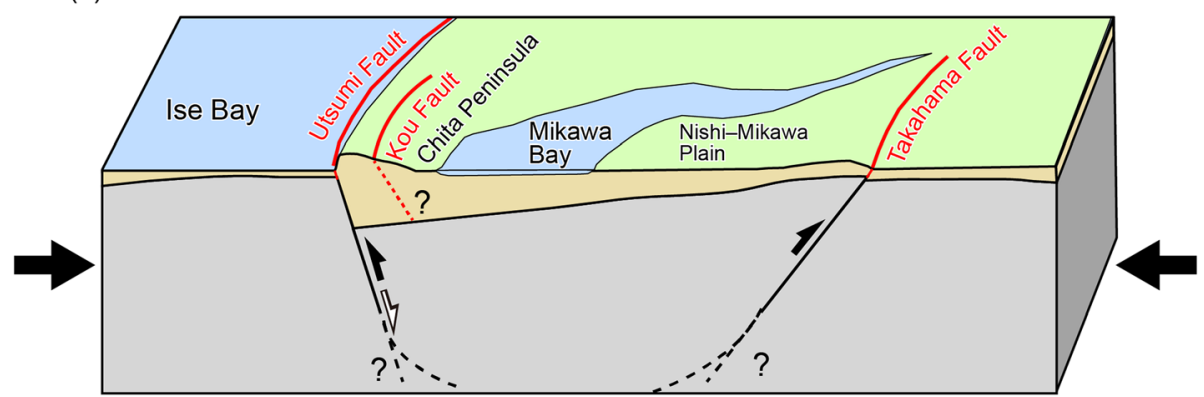

Fig. 11. a Conceptual models for thrust faults developed by the dip-slip inversion of a normal fault system (modified after McClay and Buchanan 1992). The white arrow represents normal faulting during the extensional stage. Black arrows indicate reverse faulting during the compressional stage following the extensional stage. b Conceptual models for the fault system across the Chita Peninsula and the Nishi-Mikawa Plain (not to scale). The white arrow represents the normal faulting in the extensional stage in Miocene. Black arrows indicate reverse faulting during the compressional stage following extensional stage in the Pliocene to Quaternary 
The tectonic history of the Chita Peninsula has been reconstructed using the sediments/sedimentary rocks observed in the region. The thick Miocene sedimentary rocks (Morozaki Group) filled the hanging wall of the Utsumi Fault; hence, the motion of the Utsumi Fault was normal in the Miocene (Aichi Prefecture 2005). The half-graben structure was formed during this extensional stage. Subsequently, Pliocene sedimentary rocks (Tokai Group) were folded with the axis of WNW-ESE before the Middle Pleistocene (Makinouchi 2019). This may suggest that the region was under moderate NNE-SSW compressional stress at this time, which also accounts for the fact that the Utsumi Fault which trends NW-SE was hardly reactivated during this stage. The Utsumi Fault reactivated as a reverse fault around $0.5 \mathrm{Ma}$ (following the depositional age of the Middle Pleistocene Taketoyo Formation) (Makinouchi 2019). The displacement of the reverse faulting was, however, insufficient to recover the gap formed during normal faulting in the Miocene.

The tectonic history of the inversion structure in the Chita Peninsula is comparable to inversion tectonics at the eastern margin of the Japan Sea in northeast Japan. The inversion structures in the eastern margin of the Japan Sea are the most completely described inversion structures in Japan (e.g., Okamura et al. 1995; Morijiri 1996). Normal faults were formed during the Early to Middle Miocene, and were reactivated in the Pliocene to Quaternary (Okamura et al. 1995). Periods of normal fault formation and reactivation in the eastern margin of Japan Sea in northeast Japan coincide with those in the Chita Peninsula. This episode of Miocene normal faulting is believed to be related to the opening of the Japan Sea, whereas the reactivation of reverse faulting motion is considered to be due to E-W compression resulting from the present tectonic setting. Although the tectonic history between central and northeast Japan differs after the opening of the Japan Sea (e.g., Hayashida et al. 1991; Jolivet et al. 1995; Lallemand and Jolivet 1986; Otofuji et al. 1985), the deduced agreement in the period of the inversion tectonics can be considered a clue to understanding the tectonic dynamics of the Japan Arc.

In particular, the onset of positive tectonic inversion in Chita $(\sim 0.5 \mathrm{Ma})$ is significantly younger than that in NE Japan (3-5 Ma). However, the period of normal faulting is the same between both the regions. Previous active fault studies also suggest that the onset of the present tectonic settings and the onset of present active faulting are early in NE Japan and late in SW Japan (e.g., Doke et al. 2012; Miyakawa and Otsubo 2017). This difference in the onset of the positive tectonic inversion and the active faulting could yield a new finding.

\subsection{The Takahama Fault under inversion tectonics}

Our results also enable us to discuss the role of the Takahama Fault in the inversion tectonic system in the Mikawa Bay Region. The Takahama Fault constitutes the NE edge of the half-graben (Figs. 8 and 9). Its basement surface is tilted from the Takahama Fault to the Utsumi Fault, although the basement surface is almost flat northeast of the Takahama Fault. Concurrently, the dip orientation of the Takahama Fault is west dipping. Consequently, the Takahama Fault is a "backthrust" of the Utsumi Fault (east dipping). The backthrusts are well observed in analog inversion tectonics experiments (McClay and Buchanan 1992) (Fig. 11a). Furthermore, fault traces of both the Takahama and Utsumi Fault observed on the ground surface are NW-SE trending, and both traces are parallel (Fig. 2). Such parallel master normal fault and backthrust relationships are observed in three-dimensional analog models reconstructing inversion tectonics (Yamada and McClay 2004). These geometrical features suggest that the Takahama Fault is a backthrust of the Utsumi Fault, which is the master normal fault of the inversion structure.

The initiation of the reverse faulting period of the Takahama Fault also suggests a conjugate relationship with the reverse faulting of the Utsumi Fault. The initiation/acceleration period of the reverse faulting of the Takahama Fault is estimated to be late Middle Pleistocene base on the analysis of boring cores around the southeastern part of the fault (Abe et al. 2019a, 2019b). This period is a similar one as that of the initiation of reverse faulting of the Utsumi Fault implied from the formation of the Chita Peninsula in late Middle Pleistocene (Makinouchi 2019). The simultaneity of the initiation of reverse faulting suggests that the Takahama and Utsumi faults are parts of the same inversion tectonic system.

The deep extent of the Takahama Fault within the basement rock cannot be detected by the present gravity survey. However, if the Takahama Fault is the backthrust of the Utsumi Fault, it should reach seismogenic depths. The slip distribution of the 1945 Mikawa earthquake estimated by waveform inversions shows a large slip asperity on the NW-SE trending reverse fault (Kikuchi et al. 2003; Yamanaka 2004). The location of the northwestern asperity is notably correlated with the heavily damaged area, consistent with the deeper extension of the Takahama Fault ( $10 \mathrm{~km}$ depth). The strike of the Takahama Fault $\left(\mathrm{N} 45^{\circ} \mathrm{W}\right)$ is parallel to the fault model of the 1945 Mikawa earthquake described by Kikuchi et al. (2003); moreover, the tips of the fault traces are significantly correlated (see, Fig. 2). This agreement suggest that the deep extension of the Takahama Fault can explain the fault model of the northwestern asperity described in Kikuchi et al. (2003) and Yamanaka (2004). The dip of the fault model $\left(30^{\circ} \mathrm{W}\right)$ in these studies is, however, 
lower than the dip estimated in this study $\left(\sim 60^{\circ} \mathrm{W}\right)$. This discrepancy may be solved by assuming listric fault geometry in the deeper portion of the Takahama Fault. Based on the leveling data collected by the local government, the $40-\mathrm{cm}$ subsidence of the footwall side (NE side) relative to the hanging wall side along the Takahama Fault in the 1945 Mikawa earthquake (Iida and Sakabe 1972) supports evidence for reverse faulting of the Takahama Fault during the earthquake. On the other hand, several studies suggest that the N-S trending reverse faults in the southwestward of the Nishi-Mikawa Plain (i.e., the Yokosuka and Fukouzu Faults) were predominant factors in surface faulting during the earthquake (e.g., Ando 1974; Sugito and Okada 2004; Takano and Kimata 2009). Although remarkable fractures appear on the ground surface along the Yokosuka and Fukouzu faults where the basement rock is shallow or exposed, the thick and soft Quaternary sediment and Miocene to Pliocene sedimentary rocks covering the Takahama Fault (Aichi Prefecture, 2002a, b, 2004, 2005) may reduce the ground deformation along the Takahama Fault. Therefore, the deep extension of the Takahama Fault, the back thrust of the Utsumi Fault, may be one possible source fault for the 1945 Mikawa earthquake, but this remains difficult to conclude unambiguously.

\section{Conclusions}

We analyzed gravity data to describe the basement surface structure in the Mikawa Bay Region. The gravity basement map showed the deepening of the basement surface from the Nishi-Mikawa Plain to the Chita Peninsula. Two-dimensional modeling constrained the orientation of the Utsumi and Takahama faults, although the basement surface structure related to the Kou Fault is so minor that the gravity data cannot constrain it. The basement surface structure from the Nishi-Mikawa Plain to the Chita Peninsula revealed a half-graben structure defined by the Utsumi Fault. The inverse motion of the Utsumi Fault, which underwent normal faulting during the Miocene and recent reverse faulting, is interpreted in terms of the inversion tectonics of the half-graben. These inversion tectonics, reflecting the reverse faulting of the Miocene normal fault, are comparable to the basin inversion observed at the eastern margin of the Japan Sea in northeastern Japan. The Takahama Fault in the southwestern part of the NishiMikawa Plain is considered to have formed during the backthrust of the Utsumi Fault under inversion tectonics. If the Takahama Fault is indeed the backthrust fault of the Utsumi Fault, the root of the Takahama Fault may be so deep as to reach the seismogenic depth, suggesting that the Takahama Fault may be the source fault of the 1945 Mikawa earthquake.

\section{Supplementary information}

Supplementary information accompanies this paper at https://doi.org/10. 1186/s40645-020-00376-6.

Additional file 1: Supplementary Table S1. Observed gravity data in the Nishi-Mikawa Plain, Japan.

Additional file 2: Supplementary Table S2. Elevation of the basement surface compiled in this study.

Additional file 3: Supplementary Table S3. Parameters for the 2D basement model calculated from 10 genetic algorithm (GA) experiments Additional file 4: Supplementary Figure 1 and Figure 2.

\section{Abbreviations}

GA: Genetic algorithm

\section{Acknowledgements}

We are grateful to T. Komatsubara, T. Sato, S. Okuma, and R. Nakashima (Geological survey of Japan, AIST) for their support for our project. The GNSS data were analyzed by Y. Takahashi, who is the staffs of Geological Survey of Japan, AIST. Prof. H. Hoshi (Aichi University of Education) gives us impressive comments. Some figures were generated using Generic Mapping Tools (Wessel et al. 2013). We appreciate Aichi Prefecture and Nishio City offering their boring data. Constructive comments from the editor, Yo Fukushima, and journal reviewers, Yasutaka Ikeda and an anonymous reviewer, are greatly appreciated.

\section{Authors' contributions}

AM conducted the gravity observation, analysis, and designed the study. TA proposed the topic and supported to compile related information. TS proposed the plan of the analysis and supported the analysis. MO collaborated with the corresponding author in the construction of manuscript. All authors read and approved the final manuscript.

\section{Funding}

Not applicable.

\section{Availability of data and materials}

The dataset supporting the conclusions of this article is included within the article and its additional file. Some datasets is available in the cited database in the article.

\section{Competing interests}

The authors declare that they have no competing interest.

Received: 17 May 2020 Accepted: 15 September 2020

Published online: 20 October 2020

\section{References}

Abe T, Nakashima R, Naya T (2019a) Reports of coring survey in Aburagafuchi Lowland, southwestern part of Nishimikawa Plain, central Japan. GSJ Interim Report 79:71-86 (in Japanese with English abstract) https://www.gsj.jp/data/ coastal-geology/GSJ_INTERIMREP_079_2019_07.pdf

Abe T, Nakashima R, Naya T, Mizuno K (2019b) Subsurface geology along the Takahama Fault in the southwestern part of the Nishimikawa Plain. Annual Meeting of the Association of Japanese Geographers, Autumn 2019, The Association of Japanese Geographers. (in Japanese). https://doi.org/10.14866/ ajg.2019a.0_172

Aichi Prefecture (1996) Report of the research on the active faults in the North Chita and the East Kinuura Areas. (in Japanese).

Aichi Prefecture (2000) Underground structure in the Nobi plain (in Japanese). http://www.hp1039.jishin.go.jp/kozo/Aichi6Cfrm.htm (Accessed 14 Aug 2020) Aichi Prefecture (2002a) Subsurface survey report of sedimentary basin under the Mikawa Plain. Aichi Prefecture in 2001, Nagoya. (in Japanese) http://www.hp1 039.jishin.go.jp/kozo/Aichi6Bfrm.htm (Accessed 14 Aug 2020)

Aichi Prefecture (2002b) Subsurface survey report of sedimentary basin under the Mikawa Plain. Aichi Prefecture in 2002, Nagoya. (in Japanese) http://www.hp1 039.jishin.go.jp/kozo/Aichi7Bfrm.htm (Accessed 14 Aug 2020) 
Aichi Prefecture (2004) Subsurface survey report of sedimentary basin under the Mikawa Plain. Aichi Prefecture in 2003, Nagoya. (in Japanese) http://www.hp1 039.jishin.go.jp/kozo/Aichi8frm.htm (Accessed 14 Aug 2020)

Aichi Prefecture (2005) Subsurface survey report of sedimentary basin under the Mikawa Plain. Aichi Prefecture in 2004, Nagoya. (in Japanese) http://www.hp1 039.jishin.go.jp/kozo/Aichi9Bfrm.htm (Accessed 14 Aug 2020)

Ando M (1974) Faulting in the Mikawa earthquake of 1945. Tectonophysics 22(12):173-186. https://doi.org/10.1016/0040-1951(74)90040-7

Chujo J, Suda Y (1971) Gravitational survey of northern Ise Bay. Bull Geol Surv Jpn 22(8):415-435 (in Japanese with English abstract) https://www.gsj.jp/data/ bull-gsj/22-08_02.pdf

Chujo J, Suda Y (1972) Gravitational survey of southern Ise Bay and Mikawa Bay. Bull Geol Surv Jpn 23(10):573-594 (in Japanese with English abstract) https:// www.gsj.jp/data/bull-gsj/23-10_01.pdf

Doke R, Tanikawa S, Yasue K, Nakayasu A, Niizato T, Umeda K, Tanaka T (2012) Spatial patterns of initiation ages of active faulting in the Japanese Islands. Active Fault Research 37:1-15 (in Japanese with English abstract). https://doi. org/10.11462/afr.2012.37_1

Geological Survey of Japan (2013) Gravity database of Japan. DVD edition, Digital Geoscience Map P-2. Geological Survey of Japan, AIST, Tsukuba

Goldberg DE (1989) Genetic algorithms in search, optimization, and machine learning. Addison-Wesley, Boston

Goto H (2013) Submarine anaglyph images around Japan Islands based on bathymetric charts: Explanatory text and sheet maps. Hiroshima Univ Stud Grad Sch Lett 72:1-74, (In Japanese with English abstract). https://doi.org/10. $15027 / 35603$

Gravity Research Group in Southwest Japan (2001) Gravity database of Southwest Japan (CD-ROM). Bull Nagoya University Museum, Special Report No. 9. Nagoya University Museum, Nagoya

GSJ Gravity Survey Group (1989) On the standard procedure SPECG1988 for evaluating the correction of gravity at the Geological Survey of Japan. Bull Geol Surv Jpn 40(11):601-611 (in Japanese with English abstract) https:// www.gsj.jp/data/bull-gsj/40-11_02.pdf

Hayashida A, Fukui T, Torii M (1991) Paleomagnetism of the Early Miocene Kani Group in southwest Japan and its implication for the opening of the Japan Sea. Geophys Res Lett 18(6):1095-1098. https://doi.org/10.1029/91GL01349

Headquarters for Earthquake Research Promotion (2002) Long-term evaluation of earthquake along the Ise-wan active fault zone. (in Japanese) https://www.jishin. go.jp/regional_seismicity/rs_katsudanso/f097_isewan/ (Accessed 13 Aug 2020)

Headquarters for Earthquake Research Promotion (2004) Long-term evaluation of earthquake along the Byobu-yama and Ena-san active fault zone and Sanage-yama active fault zone. (in Japanese) https://www.jishin.go.jp/ regional_seismicity/rs_katsudanso/f053_054_byobu_ena_sanage/ (Accessed 24 Apr 2020)

lida K (1978) Distribution of the Earthquake damage and Seismic Intensity caused by the Mikawa earthquake of January 13, 1945. Report of the Earthquake Section of Disaster Prevention Committee of Aichi Prefecture. Aichi Prefecture, Nagoya (in Japanese)

lida K, Sakabe K (1972) The extension of the Fukozu fault associated with the Mikawa earthquake in 1945. Zisin 24:44-55. (in Japanese with English abstract). https://doi.org/10.4294/zisin1948.25.1_44

Imaizumi T, Miyauchi T, Tsutsumi H, Nakata T (2018) Digital active fault map of Japan [Revised Edition]. University of Tokyo Press, Tokyo (in Japanese)

Iwabuchi Y, Nishikawa H, Noda N, Kawajiri C, Nakagawa M, Aoto S, Kato I, Amma K, Nagata S, Kadoya M (2000) Active faults surveys in the Ise Bay. Rep Hydrogr Res 36:73-96 (in Japanese with English abstract) https://www1. kaiho.mlit.go.jp/GIJUTSUKOKUSAI/KENKYU/report/rhr36/rhr36-05.pdf

Jolivet L, Shibuya H, Fournier M (1995) Paleomagnetic rotations and the Japan Sea opening. In: Taylor B, Natland J (eds) Active margins and marginal basins of the western Pacific, Geophysical Monograph Series, vol 88. American Geophysical Union, Washington, D. C., pp 355-369. https://doi.org/10.1029/ GM088p0355

Kikuchi M, Nakamura M, Yoshikawa K (2003) Source rupture processes of the 1944 Tonankai earthquake and the 1945 Mikawa earthquake derived from low-gain seismograms. Earth Planets Space 55(4):159-172. https://doi.org/10. 1186/BF03351745

Kondo Y, Kimura I (1987) Geology of the Morozaki district. With geological map of Japan 1:50,000, Morozaki. Geological Survey of Japan, Tsukuba. (in Japanese with English abstract)

Kuwahara T (1982) Subsurface geology and ground subsidence in Nishimikawa Region (Old Yahagi river drainage basin). Reports on survey, research and countermeasure for ground subsidence, vol 8. Environmental Department of Aichi Prefecture, pp 95-136 (in Japanese)

Lallemand S, Jolivet L (1986) Japan Sea: a pull-apart basin? Earth Planet Sci Lett 76(3-4):375-389. https://doi.org/10.1016/0012-821X(86)90088-9

Makimoto H, Yamada N, Mizuno K, Takada A, Komazawa M, Sudo S (2004) Geological Map of Japan 1:200,000, Toyohashi and Irago Misaki. Geological Survey of Japan, Tsukuba (in Japanese with English abstract)

Makino M, Endo S (1999) Gravity survey around the area of the Hariharagawa debris flow at Izumi, Kagoshima Prefecture. Butsuri-Tansa 52:153-160 (in Japanese with English abstract)

Makinouchi T (1979) Chita Movements, the tectonic movements preceding the Quaternary Rokko and Sanage Movements. Memoirs of the Faculity of Science, Kyoto University, Series of Geology and Mineralogy, 46、61-106. https://repository.kulib.kyoto-u.ac.jp/dspace/handle/2433/186632

Makinouchi T (2019) Active faults in Chita Peninsula and large earthquakes in the Nankai Trough. Chita Peninsula: its history and present 23:1-20. (in Japanese) http://id.nii.ac.jp/1274/00003183/ (Accessed 24 Apr 2020)

McClay KR, Buchanan PG (1992) Thrust faults in inverted extensional basins. In: McClay KR (ed) Thrust tectonics. Springer, Dordrecht, pp 93-104. https://doi. org/10.1007/978-94-011-3066-0_8

Ministry of Land, Infrastructure, Transport and Tourism (2008): Kunijiban, http:// www.kunijiban.pwri.go.jp/ (Accessed 9 Sep 2020)

Miyakawa A, Otsubo M (2017) Evolution of crustal deformation in the northeastcentral Japanese island arc: Insights from fault activity. Island Arc. 26(2): e12179. https://doi.org/10.1111/iar.12179

Morijiri R (1996) Subsurface structure of the southeastern margin of the Japan Sea inferred from Bouguer gravity anomalies. Zishin (J Seismol Soc Jpn 2nd ser) 49(3):403-416. https://doi.org/10.4294/zisin1948.49.3_403 (in Japanese with English abstract)

Murata Y, Miyakawa A, Komazawa M, Nawa K, Okuma S, Joshima M, Nishimura K, Kishimoto K, Miyazaki T, Shichi R, Honda R, Sawada A (2018) Gravity map of Kanazawa District, gravity map series (Bouguer Anomalies) 33. Geological Survey of Japan, AIST, Tsukuba (in Japanese with English abstract) https:// www.gsj.jp/Map/EN/geophysics.html (Accessed 24 Apr 2020)

National Institute of Advanced Industrial Science and Technology (2020a) Active fault database of Japan, Research Information Database DB095, National Institute of Advanced Industrial Science and Technology. https://gbank.gsj.jp/ activefault/index_e_gmap.html. (Accessed 22 Apr 2020)

National Institute of Advanced Industrial Science and Technology (2020b) Seamless digital geological map of Japan (1:200,000), https://gbank.gsj.jp/ seamless/v2/viewer/?lang=en. (Accessed 28 Apr 2020)

National Research Institute for Earth Science and Disaster Resilience (2019) NIED K-NET, KiK-net, National Research Institute for Earth Science and Disaster Resilience, doi:10.17598/NIED.0004 https://www.kyoshin.bosai.go.jp/kyoshin/ db/index_en.html?all\%22 (Accessed 9 Sep 2020)

Nettleton LL (1939) Determination of density for reduction of gravimeter observations. Geophys 4(3):176-183

Okada A, Toyokura I, Makinouchi T, Fujiwara Y, Ito T (2000) The Ise Bay fault off the Chita Peninsula, Central Japan. J Geogr (Chigaku Zasshi) 109(1): 10-26. https://doi.org/10.5026/jgeography.109.10 (in Japanese with English abstract)

Okamura Y, Watanabe M, Morijiri R, Satoh M (1995) Rifting and basin inversion in the eastern margin of the Japan Sea. Isl Arc 4(3):166-181. https://doi.org/10. 1111/j.1440-1738.1995.tb00141.x

Otofuji Yl, Matsuda T, Nohda S (1985) Opening mode of the Japan Sea inferred from the palaeomagnetism of the Japan Arc. Nature 317(6038):603-604. https://doi.org/10.1038/317603a0

Schön JH (2004) Physical properties of rocks: fundamentals and principles of petrophysics. Elsevier

Sugito N, Okada A (2004) Surface rupture associated with the 1945 Mikawa earthquake. Active Fault Res 24:103-127. https://doi.org/10.11462/afr1985. 2004.24_103 (in Japanese with English abstract)

Takano K, Kimata F (2009) Re-examination of ground deformation and fault models of the 1945 Mikawa Earthquake $(M=6.8$ ). Zisin (J Seismol Soc Jpn 2nd ser) 62(2+3):85-96. https://doi.org/10.4294/zisin.62.85 (in Japanese with English abstract)

Talwani M (1973) Computer usage in the computation of gravity anomalies. Method in Computational Physics, vol 13. Academic Press, New York, pp 343-389. https://doi.org/10.1016/B978-0-12-460813-9.50014-X

Wei D, Seno T (1998) Determination of the Amurian plate motion. In: Flower MFJ, Chung SL, Lo CH, Lee TY (eds) Mantle dynamics and plate interactions in 
East Asia. Geodynamics Series, vol 27. American Geophysical Union, Washington D. C., pp 337-346. https://doi.org/10.1029/GD027p0337

Wessel P, Smith WHF, Scharroo R, Luis J, Wobbe F (2013) Generic mapping tools: Improved version released. EOS Trans AGU 94(45):409-410. https://doi.org/10. 1002/2013EO450001

Yamada T, Takada Y, Yamada N, Asao K, Ohtomo Y (1984) A new fact on the location of the Median Tectonic Line around Cape Irago, Atsumi Peninsula, central Japan. The Journal of the Geological Society of Japan 90(12):915-918. https://doi.org/10.5575/geosoc.90.915 (in Japanese)

Yamada Y, McClay K (2004) 3-D analog modeling of inversion thrust structures. In: McClay KR (ed) thrust tectonics and hydrocarbon systems. AAPG Memoir, vol 82. American Association of Petroleum Geologists, Tulsa, pp 276-301. https://doi.org/10.1306/M82813C16

Yamamoto A, Shichi R, Kudo T (2011) Gravity database of Japan (CD-ROM). Special publication No. 1. The Earth Watch Safety Net Research Center. Chubu University, Nagoya

Yamanaka Y (2004) Source rupture processes of the 1944 Tonankai earthquake and the 1945 Mikawa earthquake. The Earth Monthly 26(11):739-745 (in Japanese)

\section{Publisher's Note}

Springer Nature remains neutral with regard to jurisdictional claims in published maps and institutional affiliations.

\section{Submit your manuscript to a SpringerOpen ${ }^{\circ}$ journal and benefit from:}

- Convenient online submission

- Rigorous peer review

- Open access: articles freely available online

High visibility within the field

- Retaining the copyright to your article

Submit your next manuscript at $\boldsymbol{\nabla}$ springeropen.com 